\title{
EFFICIENCY OF ANDIROBA, COPAIBA AND JATROPHA OILS TO IMPROVE THE RESISTANCE OF Pinus elliottii WOOD TO WOOD-DECAY FUNGI
}

Sara Freitas de Souza ${ }^{\circledR}$, Juarez Benigno Paes $^{3 *} \odot$, Marina Donária Chaves Arantes ${ }^{4} \odot$, Luciana Ferreira da Silva $^{5}$ and Larissa Dudecki ${ }^{3}$ (둥

\footnotetext{
${ }^{1}$ Received on 19.07.2019 accepted for publication on 13.02.2020.

${ }^{2}$ Universidade Federal do Oeste do Pará, Programa de Pós-Graduação em Ciências Ambientais, Santarém, PA-Brasil. E-mail: <sara freitas_stm@hotmail.com>.

${ }^{3}$ Universidade Federal do Espírito Santo, Departamento de Ciências Florestais e da Madeira, Jerônimo Monteiro, ES-Brasil. E-mail: $<$ jbp2@uol.com.br> and <1.dudecki@hotmail.com>.

${ }^{4}$ Universidade Federal de São Jão del Rei, Departamento de Engenharia Florestal, Sete Lagoas, MG-Brasil. E-mail: <mdonariac@ufsj. edu.br>.

${ }^{5}$ Universidade Federal do Espírito Santo, Programa de Pós-Graduação em Ciências Florestais, Jerônimo Monteiro, ES-Brasil. E-mail: <lu. ferreira1@hotmail.com>.

*Corresponding author.
}

\begin{abstract}
Non-renewable chemical products are still the most used for wood protection, however, they have negative aspects. Several problems associated with the extensive use of these substances have been reported, such as intoxication of animals and plants, and environmental contamination. This has led to a search for alternative methods of control that cause less impact on the environment. In this context, the use of natural products extracted from different plants can be an alternative to this industrial activity. The objective of this work was to evaluate the efficiency of andiroba, copaiba and jatropha oils, either pure or enriched with iodine $\left(\mathrm{I}_{2}\right)$, to improve the biological resistance of Pinus elliottii wood to wood-decay fungi causing brown, white and soft rot. The andiroba and copaiba oils came from the state of Pará and the jatropha oil came from Paraíba. Thus, we performed resistance tests to accelerated decay (brown and white rot fungi) and soft rot tests in the laboratory. We used pure natural oils and those enriched with sublimated iodine in assessing efficiency. In turn, we evaluated the effects of volatilization and leaching on the efficiency of solutions against decaying fungi. Pure andiroba and jatropha oils were the least efficient in controlling the Trametes versicolor fungus in the accelerated decay biological assay. Moreover, the wood treated with pure copaiba oil (normal situation) was classified as non-resistant for controlling Postia placenta fungus. In the soft rot test, we observed that there was a tendency to improve the wood resistance (normal situation) with an increase in the iodine concentration $\left(\mathrm{I}_{2}\right)$.

Keywords: Vegetable oils; Xylophagous fungi; Biological assays.
\end{abstract}

\section{EFICIÊNCIA DOS ÓLEOS DE ANDIROBA, COPAÍBA E PINHÃO MANSO NA MELHORIA DA RESISTÊNCIA DA MADEIRA DE Pinus elliottii A FUNGOS APODRECEDORES}

\begin{abstract}
RESUMO - Os produtos químicos não renováveis ainda são os mais utilizados para proteção da madeira, porém possuem aspectos negativos. Diversos problemas associados ao uso extensivo dessas substâncias são relatados, como a intoxicação de animais e plantas e contaminação ambiental. Isto tem levado à procura por métodos alternativos de controle que ocasionem menor impacto ao ambiente. Neste contexto, o uso de produtos naturais extraidos de diferentes plantas pode ser alternativa a esta atividade industrial. O objetivo desse trabalho foi avaliar a eficiência dos óleos de andiroba, copaíba e pinhão manso, puros ou enriquecidos com iodo $\left(I_{2}\right)$ para melhorar a resistência biológica da madeira de Pinus elliottii a fungos apodrecedores, causadores das podridões parda, branca e mole. Os óleos de andiroba e copaíba foram oriundos do estado do Pará e o de pinhão-manso da Paraíba. Foram realizados os ensaios de resistência ao apodrecimento acelerado em laboratório (fungos de podridão parda e branca) e ensaio de podridão mole. Na avaliação da eficiência, os óleos naturais foram empregados puros e enriquecidos com iodo sublimado. Foram avaliados os efeitos da volatilização e lixiviação
\end{abstract}

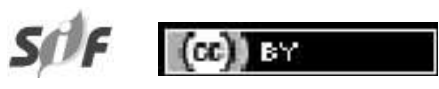

Revista Árvore 2020;44:e4430 http://dx.doi.org/10.1590/1806-908820200000030 


\begin{abstract}
na eficiência das soluções contra os fungos aprodrecedores. No ensaio biológico de apodrecimento acelerado, os óleos de andiroba e pinhão manso puros foram os menos eficientes no controle do fungo Trametes versicolor. No controle do fungo Postia placenta, a madeira tratada com o óleo de copaíba puro (situação normal) foi classificada como não resistente. No ensaio de podridão mole observou-se que com o aumento da concentração de iodo $\left(I_{2}\right)$ houve tendência de melhoria da resistência da madeira (situação normal).
\end{abstract}

Palavras-Chave: Óleos vegetais; Fungos xilófagos; Ensaios biológicos.

\section{INTRODUCTION}

Wood has good resistance to external stresses and associated with low density and cost when compared to other construction materials such as iron, aluminum and steel, in addition to being a material from renewable sources (natural or implanted forests). Thus, it is used for structural purposes and in the flooring, furniture and packaging industries. However, due to its biological origin, wood is consumed (to a greater or lesser extent) by various xylophagous organisms which use its chemical components (cellulose, hemicelluloses, lignins, starch and simple sugars) as a food source.

Thus, wood is subject to deterioration which is carried out by xylophagous organisms, mainly by fungi and termites (Paes et al., 2010). Fungi are the main deteriorating agents of wood, and can be divided based on their ability to attack the cell wall components, use reserve substances (starch and simple sugars) and the type of attack caused to the wood (Goodell et al., 2003; Schmidt, 2006). However, a wood species resistance to attack by xylophagous organisms varies between forest species and even within the tree itself, which is provided by the anatomical structure of the wood and by the toxic or natural inhibiting substances contained in it (Carvalho et al., 2015).

Some woods, mainly those from implanted forests, have low resistance to xylophagous organisms, requiring treatments in order to improve their performance (Paes et al., 2005a) and meet the demand of the wood sector. Non-renewable chemicals, especially those based on copper, chromium, arsenic and boron are still the most used for wood protection. However, these chemicals have negative aspects with several problems being associated with their extensive use, such as the intoxication of animals and plants, as well as environmental contamination (Bossardi and Barreiros, 2011).

Modern society has recently been concerned with the preservation of environmental resources and human health. This has led to a search for cleaner technologies, aiming to minimize the losses caused by the use of harmful substances (Appel et al., 2006). In addition, there is also a search for alternative control methods which cause less impact on the environment, such as the use of natural products extracted from different plant species (Paes et al., 2010; Paes et al., 2012; Teixeira et al., 2015; Medeiros et al., 2016; Brocco et al., 2017; Balfas, 2019; Sousa et al., 2019).

Research development leads to improvements in resistance to xylophagous organisms. The use of natural products in wood could replace those of traditional uses which contain toxic compounds in their formulation (Paes et al., 2010; Teixeira et al., 2015) for treating wood which will come into contact with humans or food. Thus, andiroba (Carapa guianensis), copaiba (Copaifera langsdorffii) and jatropha (Jatropha curcas) oils, which are already used as biodiesel, lubricants, paints and varnishes (Gonçalves, 2001; Arruda et al., 2004) and insecticides and fungicides (Freire et al., 2006; Deus et al., 2011; Oliveira et al., 2013), could be used for such purposes.

In some cases, plant oils and extracts need chemicals added which are not harmful to human health and the environment in order to have their effectiveness improved. Iodine has bactericidal, fungicidal and insecticidal action (Costa et al., 2003), and mainly due to its low toxicity to humans and the environment (Takahashi et al., 1985) associated with its low solubility in water (Moriya and Módena, 2008), it may provide resistance strength to wood. This is very interesting to the industry, since the active principle will remain when it is exposed to environmental action.

Thus, the aim of this study was to evaluate the efficiency of andiroba, copaiba and jatropha oils, pure or enriched with iodine $\left(\mathrm{I}_{2}\right)$, to improve the biological resistance of Pinus elliottii wood to wood-decay fungi causing brown, white and soft rot.

Revista Árvore 2020;44:e4430 


\section{MATERIAL AND METHODS}

\subsection{Origin of oils, preparation and wood treatment}

The oils used came from different regions; andiroba and copaiba oils came from the state of Pará and jatropha oil came from Paraíba, Brazil. The Pinus elliottii wood used in the experiment was obtained in the form of $10 \times 10 \times 300 \mathrm{~cm}$ (width $\times$ thickness $\times$ length) beams from plantations aged 21 years. The beams were sawn to remove samples in the appropriate dimensions for each biological test, and then they were selected by discarding those with defects (knots, resin bags and cracks), sanded, and identified.

Before treating the wood, we maintained the specimens in an oven at $103 \pm 2{ }^{\circ} \mathrm{C}$ until constant mass and checked their volumes. We used the cold immersion method for wood impregnation, in which we submerged the samples in pure oils or enriched with $1 \%, 3 \%$ and $5 \%$ of $\mathrm{I}_{2}$ ( $\mathrm{I}_{2}$ mass:oil volume) until reaching a retention of 50 to $70 \mathrm{~kg} \mathrm{~m}^{-3}$. We weighed the specimens before and after impregnation and then they were subjected to three situations (leachate, volatilized and normal). In the normal situation, we used the samples after they were impregnated with the oils for testing with xylophagous fungi.

We used the methodology described by Freitas (1970) for the leaching test, in which the specimens are exposed in a container with water circulation at a flow regulated to $400 \mathrm{~mL} \mathrm{~min}^{-1}$ for 150 hours. After this procedure, we

Table 1 - Description of treatments and situations used in Pinus elliottii samples.

Tabela 1 - Descrição dos tratamentos e situações utilizadas nas amostras de Pinus elliottii.

\begin{tabular}{cc}
\hline Treatment & Description of treatments \\
\hline 1 & Control (wood without treatment) \\
2 & Andiroba Pure \\
3 & Andiroba enriched with 1\% Iodine \\
4 & Andiroba enriched with 3\% Iodine \\
5 & Andiroba enriched with 5\% Iodine \\
6 & Copaiba Pure \\
7 & Copaiba enriched with 1\% Iodine \\
8 & Copaiba enriched with 3\% Iodine \\
9 & Copaiba enriched with 5\% Iodine \\
10 & Jatropha Pure \\
11 & Jatropha enriched with 1\% Iodine \\
12 & Jatropha enriched with 3\% Iodine \\
13 & Jatropha enriched with 3\% Iodine \\
\hline Situation & Description of situation \\
\hline 1 & Leached \\
2 & Volatilized \\
3 & Normal \\
\hline
\end{tabular}

conditioned the samples for 15 days (temperature of $25 \pm$ $2^{\circ} \mathrm{C}$ and $65 \pm 5 \%$ relative humidity - $\left.\mathrm{RH}\right)$.

We employed the American Society for Testing and Materials - ASTM D-1413 (2008) methodology for the volatilization test, in which we immersed the samples in distilled water for 2 hours, followed by exposure in a forced circulation oven at $48.9 \pm 1.1^{\circ} \mathrm{C}$ for 334 hours.

We then performed accelerated decay and resistance to soft rot fungi tests after the samples were impregnated (normal situation) or subjected to volatilization and leaching. The tested treatments and situations are described in Table 1.

\subsection{Accelerated decay test}

We followed the specifications of ASTM D-1413 (2008) to perform the accelerated decay test, in which we tested six $1.9 \mathrm{~cm}$-edge cubic samples per treatment used (Table 1). We did not compare fungal attacks to each other.

Next, we prepared $600 \mathrm{~mL}$ flasks filled with $300 \mathrm{~g}$ of soil of $\mathrm{pH} 7.1$ and water retention capacity of $26 \%$. We corrected the humidity in the soil used to fill the containers to $130 \%$ of the retention capacity by adding $93 \mathrm{~mL}$ of distilled water, and added two Pinus elliotti wooden feeder strips. We sterilized the flasks in an autoclave at $103 \mathrm{kPa}$ and $121^{\circ} \mathrm{C}$ for 30 minutes.

After cooling, we inoculated pure culture fungi fragments of Gloeophyllum trabeum (Pers.) Murrill (Mad. 617); Postia placenta (Fr.) M.J. Larsen \& Lombard (Mad. 698), which causes brown rot; and Trametes versicolor (L.) Lloyd (Mad. 697), which causes white rot. Next, we added the test specimens at the rate of two per flask after approximately one month, when complete colonization of the microorganism in the feeders and in the soil was noticeable.

Table 2 - Classification of mass loss in a resistance test to xylophagous fungi.

Tabela 2 - Classificação da perda de massa em ensaio de resistência a fungos xilófagos.

\begin{tabular}{ccc}
\hline Mass Loss (\%) & Residual Mass (\%) & Resistance Class \\
\hline $0-10$ & $90-100$ & Highly Resistant \\
& & (HR) \\
$11-24$ & $76-89$ & Resistant (R) \\
$25-44$ & $56-75$ & Moderately \\
& & Resistant (MR) \\
$\geq 45$ & $\leq 55$ & Non-Resistant \\
& & (NR) \\
Source: ASTM D - 2017 (2008). &
\end{tabular}

Fonte: ASTM D - 2017 (2008).

Revista Árvore 2020;44:e4430 
The test was kept in an air-conditioned room $(25 \pm$ $2^{\circ} \mathrm{C}$ and $65 \pm 5 \% \mathrm{RH}$ ) for 12 weeks. After this period, we removed the samples from the flasks and removed the fungi mycelia under running water using a soft bristle brush in order to further analyze the mass loss caused in the wood (corrected by the operational loss), which we evaluated according to ASTM D-2017 (2008) (Table 2).

\subsection{Resistance test to soft rot fungi}

We used the methodology described by the Institute for Technological Research/Wood Division - IPT/ DIMAD D-5 (1980) for the resistance test to soft rot fungi, which recommends the use of $3.0 \times 1.5 \times 0.5 \mathrm{~cm}$ specimens (longitudinal $\mathrm{x}$ radial $\mathrm{x}$ tangential). This test aims to subject the material to natural microflora action existing in organic soils ("garden" soil). The specimens were buried in organic soil removed under natural forest.

The specimens were treated with andiroba, copaiba and jatropha oils, either pure or enriched with 1\%, 3\% and $5 \% \mathrm{I}_{2}$ ( $\mathrm{I}_{2}$ mass:oil volume), in addition to being subjected to the three situations mentioned [(leachate, volatilized and normal (samples only impregnated)], as shown in Table 1. In this test, we filled $600 \mathrm{~mL}$ flasks with $300 \mathrm{~g}$ of soil with a $\mathrm{pH}$ of 5.3 and water retention capacity of $31.87 \%$. We adjusted the moisture content of the soil to $100 \%$ of the water retention capacity according to the methodological recommendation, and added $80 \mathrm{~mL}$ of distilled water.

After this procedure, we added two specimens to each flask. The test remained in an air-conditioned room $\left(25 \pm 2{ }^{\circ} \mathrm{C}\right.$ and $\left.65 \pm 5 \% \mathrm{RH}\right)$ for 120 days. We used 10 samples per treatment; six of these were buried in natural soil, and four in sterile soil $\left(103 \mathrm{kPa}\right.$ and $121^{\circ} \mathrm{C}$ for $30 \mathrm{~min}$ ).

We removed the specimens from the flasks after 120 days and also removed the fungi mycelium, then placed the specimens in an oven $\left(103 \pm 2{ }^{\circ} \mathrm{C}\right)$ until they reached their constant mass and weighed them to assess the mass loss (ASTM D - 2017, 2008), which was corrected according to the samples buried in sterile soil.

\subsection{Statistical analysis and evaluation of the results}

We used a completely randomized design with a factorial arrangement in the biological tests. Next, we evaluated the effects of the treatments (13 levels) to which the samples were submitted (three levels) with 13 x 3 factorial (Table 1), totaling 39 treatments. We did not compare the fungi to each other.
We verified the data normality (Lilliefors test, $\mathrm{p}<$ 0.05 ) and the homogeneity of the variances (Cochran test, $\mathrm{p}<0.05)$. We transformed the percentage values of the mass loss into arcsen [root (mass loss/100] when necessary. This transformation was suggested by Steel and Torrie (1980), and was necessary to enable homogeneity of the variances. We used the Scott-Knott test $(p<0.05)$ for the factors and interactions detected as being significant by the F-test $(p<0.05)$.

\section{RESULTS}

\subsection{Accelerated decay test}

The test results for the Gloeophyllum trabeum fungus strain used were discarded because it had unsatisfactory growth, even in the flasks which contained the control samples produced with Pinus elliotti. This probably occurred due to a lack of subculturing in the fungi sample, which caused little vigor and low development in the flasks during the soil-block test recommended by ASTM D-1413 (2008).

The analysis of variance of the mass loss related to the accelerated decay laboratory test for the Trametes

Table 3 - Comparison between the mass loss averages and classification of the wood resistance for each treatment and situation for the Trametes versicolor fungus.

Tabela 3 - Comparação entre as médias de perda de massa e classificação da resistência da madeira para cada tratamento e situação, para ofungo Trametes versicolor.

\begin{tabular}{ccc}
\hline Treatment & Mass loss (\%) & Classification \\
\hline 1 & $18.42 \mathrm{a}$ & $\mathrm{R}$ \\
2 & $15.58 \mathrm{~b}$ & $\mathrm{R}$ \\
3 & $8.83 \mathrm{c}$ & $\mathrm{HR}$ \\
4 & $8.81 \mathrm{c}$ & $\mathrm{HR}$ \\
5 & $8.71 \mathrm{c}$ & $\mathrm{HR}$ \\
6 & $9.45 \mathrm{c}$ & $\mathrm{HR}$ \\
7 & $9.34 \mathrm{c}$ & $\mathrm{HR}$ \\
8 & $8.82 \mathrm{c}$ & $\mathrm{HR}$ \\
9 & $10.23 \mathrm{c}$ & $\mathrm{HR}$ \\
10 & $15.85 \mathrm{~b}$ & $\mathrm{R}$ \\
11 & $9.29 \mathrm{c}$ & $\mathrm{HR}$ \\
12 & $8.88 \mathrm{c}$ & $\mathrm{HR}$ \\
13 & $9.29 \mathrm{c}$ & $\mathrm{HR}$ \\
\hline Situation & Mass loss (\%) & $\mathrm{HR}$ \\
\hline 1 & $9.80 \mathrm{~b}$ & $\mathrm{R}$ \\
2 & $11.60 \mathrm{a}$ & $\mathrm{R}$ \\
\hline 3 & $11.25 \mathrm{a}$ & \\
\hline Averages followed by the same letter do not differ (Scott-Knott; $\mathrm{p}>0.05)$. HR \\
- Highly resistant; R - Resistant (ASTM D - 2017, 2008). T1...T13, treatments \\
(Table 1). Situation 1: leached; Situation 2: volatilized; Situation 3: normal. \\
Médias seguidas pela mesma letra não diferem entre si (Scott-Knott; $p>$ \\
, 05). HR - Altamente resistente; $R$ - Resistente (ASTM D - 2017, 2008). T1.... \\
T13, tratamentos (Tabela 1). Situação 1: lixiviado; Situação 2: volatilizado; \\
Situação 3: normal. & &
\end{tabular}

Revista Árvore 2020;44:e4430 
Table 4 - Comparison between the average mass loss of treatments and situations for the Postia placenta fungus.

Tabela 4 - Comparação entre as médias de perda de massa dos tratamentos e situações para o fungo Postia placenta.

\begin{tabular}{|c|c|c|c|}
\hline \multirow{2}{*}{ Treatment } & \multicolumn{3}{|c|}{ Situation / Loss of Mass (\%) } \\
\hline & Leached (1) & Volatilized (2) & Normal (3) \\
\hline 1 & $58.17 \mathrm{aA}(\mathrm{NR})$ & $57.76 \mathrm{aA}(\mathrm{NR})$ & $56.69 \mathrm{aA}(\mathrm{NR})$ \\
\hline 2 & $49.07 \mathrm{bA}(\mathrm{NR})$ & 39.17 bB (MR) & $35.63 \mathrm{bB}(\mathrm{MR})$ \\
\hline 3 & 39.09 cA (MR) & $28.71 \mathrm{cA}(\mathrm{MR})$ & $33,91 \mathrm{bA}(\mathrm{MR})$ \\
\hline 4 & 29.20 cA (MR) & $11.30 \mathrm{~dB}(\mathrm{R})$ & $24.15 \mathrm{cA}(\mathrm{R})$ \\
\hline 5 & $17.33 \mathrm{dA}(\mathrm{R})$ & $10.38 \mathrm{dA}(\mathrm{HR})$ & $20.73 \mathrm{cA}(\mathrm{R})$ \\
\hline 6 & $11.42 \mathrm{dC}(\mathrm{R})$ & $32.93 \mathrm{cB}(\mathrm{MR})$ & $50.61 \mathrm{aA}(\mathrm{NR})$ \\
\hline 7 & $9.51 \mathrm{~dB}(\mathrm{HR})$ & $26.63 \mathrm{cA}(\mathrm{MR})$ & $18.31 \mathrm{cA}(\mathrm{R})$ \\
\hline 8 & $8.70 \mathrm{~dB}(\mathrm{HR})$ & $31.06 \mathrm{cA}(\mathrm{MR})$ & $39.66 \mathrm{bA}(\mathrm{MR})$ \\
\hline 9 & $8.64 \mathrm{~dB}(\mathrm{HR})$ & $15.79 \mathrm{~dB}(\mathrm{R})$ & $29.00 \mathrm{cA}(\mathrm{MR})$ \\
\hline 10 & $46.53 \mathrm{bA}(\mathrm{NR})$ & $42.24 \mathrm{bA}(\mathrm{MR})$ & $40.82 \mathrm{bA}(\mathrm{MR})$ \\
\hline 11 & $34.24 \mathrm{cA}(\mathrm{MR})$ & $32.98 \mathrm{cA}(\mathrm{MR})$ & $24.68 \mathrm{cA}(\mathrm{R})$ \\
\hline 12 & 30.49 cA (MR) & $11.18 \mathrm{~dB}(\mathrm{R})$ & $29.67 \mathrm{cA}(\mathrm{MR})$ \\
\hline 13 & $14.81 \mathrm{dA}(\mathrm{R})$ & $10.33 \mathrm{dA}(\mathrm{HR})$ & $15.68 \mathrm{cA}(\mathrm{R})$ \\
\hline
\end{tabular}

versicolor fungus showed that only the effects of the treatments and situations tested (Table 1) were significant by the F-test. The mass loss values of the treated wood differed statistically from the control (18.42\%), indicating that the solutions prepared with the oils contributed to an increase in the wood resistance to the decay caused by the tested fungus (Table 3 ).

The analysis showed that the attack by the Trametes versicolor fungus on wood differentiated according to the employed solutions (Table 3). The wood protection with the addition and increase of iodine concentration for the tested oils generally showed trends to improve, with the exception of copaiba oil.

The analysis of variance on the mass loss of the laboratory accelerated decay test for the Postia placenta fungus showed significant results by the F-test for the treatments, situation and interaction between treatments and situations, which were analyzed by the Scott-Knott test (Table 4).

In treatment 6 , pure copaiba oil, situation 3 (50.61\%), the treated wood did not statistically differ from the control, which reached a mass loss value of $56.69 \%$ in this situation (situation 3 - normal). This indicated that the fungus strain used was vigorous and capable of decaying the samples if they were not treated. According to the enrichment, it is generally noted that there was a decrease in the average mass loss in the three studied situations (1 - leachate, 2 - volatilized and 3 - normal), demonstrating fungicidal action of the solutions enriched with $\mathrm{I}_{2}$ (Table 4).

\subsection{Soft rot assay}

The mass loss variance analysis showed significant results by the F-test for the treatments, situation and interaction between treatment and situation, which were analyzed by the Scott-Knott test (Table 5).

It appears that the greatest mass losses were found for untreated Pinus elliotti wood (control) in the leached (1), volatilized (2) and normal (3) situations, with values of $6.67 ; 13.28$; and $14.25 \%$, respectively (Table 5).

\section{DISCUSSION}

\subsection{Accelerated decay test}

\subsubsection{Trametes versicolor fungus assay}

For Trametes versicolor (Table 3) we observed that the highest mass loss averages were obtained in wood treated with pure andiroba (treatment 2) and jatropha (treatments 10) oils, being $15.58 \%$ and $15.85 \%$, respectively, and as such are considered resistant by ASTM D-2017 (2008). Copaiba oil did not have significant differences between pure and iodine enriched treatments $(1 \%, 3 \%$ and $5 \%)$. The averages obtained for this oil enables inserting them in the highly resistant class, ASTM D-2017 (2008). According to Zabel and Morreal (1992), Goodell et al. (2003), and Schmidt (2006), the low mass loss caused by $T$. versicolor in the $P$. elliotti wood can be explained by the low ability of white rot fungi to attack coniferous wood. However, some white rot fungi attack both coniferous and hardwoods. 
Table 5-Comparison between the average mass loss of treatments and situations for soft rot fungus.

Tabela 5 - Comparação entre as médias de perda de massa dos tratamentos e situações para fungo de podridão mole.

\begin{tabular}{cccr}
\hline \multirow{2}{*}{ Treatment } & \multicolumn{3}{c}{ Situation / Loss of Mass (\%) } \\
\cline { 2 - 4 } & Leached (1) & Volatilized (2) & Normal (3) \\
\hline 1 & $6.67 \mathrm{aB}$ & $13.28 \mathrm{aA}$ & $14.25 \mathrm{aA}$ \\
2 & $4.48 \mathrm{aB}$ & $2.45 \mathrm{cC}$ & $7.55 \mathrm{bA}$ \\
3 & $6.42 \mathrm{aA}$ & $2.89 \mathrm{cB}$ & $3.06 \mathrm{cB}$ \\
4 & $3.04 \mathrm{bA}$ & $2.44 \mathrm{cA}$ & $2.79 \mathrm{cA}$ \\
5 & $3.70 \mathrm{bA}$ & $2.21 \mathrm{cB}$ & $0.57 \mathrm{dC}$ \\
6 & $1.95 \mathrm{cB}$ & $5.79 \mathrm{bA}$ & $4.49 \mathrm{bA}$ \\
7 & $2.85 \mathrm{bA}$ & $1.88 \mathrm{cA}$ & $3.11 \mathrm{cA}$ \\
8 & $1.88 \mathrm{cA}$ & $1.76 \mathrm{cA}$ & $2.24 \mathrm{cA}$ \\
9 & $1.29 \mathrm{cB}$ & $1.23 \mathrm{~dB}$ & $2.74 \mathrm{cA}$ \\
10 & $3.61 \mathrm{bB}$ & $4.17 \mathrm{bB}$ & $6.15 \mathrm{bA}$ \\
11 & $2.14 \mathrm{cB}$ & $4.79 \mathrm{bA}$ & $5.38 \mathrm{bA}$ \\
12 & $2.50 \mathrm{cA}$ & $0.78 \mathrm{dA}$ & $1.63 \mathrm{dA}$ \\
13 & $2.87 \mathrm{bA}$ & $2.24 \mathrm{cA}$ & $1.29 \mathrm{dA}$ \\
\hline Averages followed by the same letter do not differ (Scott-Knott; $\mathrm{p}>0.05)$. \\
T1...T13, treatments (Table 1). \\
Médias seguidas pela mesma letra não diferem entre si (Scott-Knott; $p>0,05)$. \\
T1....T13, tratamentos (Tabela 1).
\end{tabular}

For pure oils, it is noted that the lowest mass loss was for wood treated with copaiba oil (9.45\%) (treatment 6$)$, being highly resistant (HR). There are some substances which are found in this oil that are specific to the different species of the Copaifera genus, which excludes the possibility of being found in other oils or species. Its biological activity is due to its chemical composition, which is mostly composed of sesquiterpenes. It has been found that the percentage of this compound can vary from 30 to $90 \%$ in the total composition of this product (Revilla, 2001; Leite and Pastore Júnior, 2003).

The way in which terpenes act in controlling microorganisms has not yet been fully clarified, however it is assumed that this action may be related to a rupture of the membrane through bonds with lipophilic compounds (Cowan, 1999). These compounds have already been described as having several biological activities such as anesthetic, antibiotic, anthelmintic, anti-inflammatory and sedative (Craveiro and Machado, 1986).

We expected that the normal situation (3) would have lower mass losses, however we noted that the volatile situation (2) was statistically equal to the normal situation, and the two differed from situation 1 (leachate) (Table 3). We observed differences of $12.88 \%$ for the leached situation treatments when compared to the normal situation. This can be explained by the existence of compounds such as chlorine in the water used which was from the public network, and which may have been absorbed by the samples.
For treatments (tannins + copper sulfates; tannins + CCA; tannins + arsenic trioxide) in relation to untreated samples, Vital et al. (2001) also found that there were gains in wood strength (ranging from 88 to $94 \%$ ) for the situation in which the samples were leached. Moreover, there was a gain in mass loss of approximately $50 \%$ for the treatment with tannins + arsenic trioxide when the mass loss of those leached was compared to that of the non-leachate.

\subsubsection{Postia placenta fungus assay}

For Postia placenta (Table 4), we found that the samples treated with oils enriched with $5 \% \mathrm{I}_{2}$ obtained the lowest mass loss averages in the three situations, except for the treatment with copaiba oil, for which we found a mean of $18.31 \%$ when enriched with $1 \%$ iodine (treatment 7, situation 3); however, it did not differ statistically from the mass loss of the wood treated with this oil enriched with 5\% $\mathrm{I}_{2}$ (treatment 9). In situation 2, we observed the lowest average mass loss was for wood treated with jatropha oil with $5 \% \mathrm{I}_{2}(10.33 \%)$, which did not differ from treatments 4, 5, 9 and 12 of this situation.

For wood treated with jatropha oil (situation 3), we found that the greatest mass loss was obtained for pure oil with an average of $40.82 \%$, being considered moderately resistant, statistically differing from treatments 11,12 and 13 for which we found mass losses of 24.68; 29.67; and $15.68 \%$, respectively.

We also found that higher mass loss averages were obtained for the three situations (Table 4) with treatments with pure oils, thus, the enrichment contributed to greater wood protection. According to ASTM D-2017 (2008), treatments 1 (situations 1, 2 and 3), 2 (situation 1), 6 (situation 3) and 10 (situation 1) were considered non-resistant (NR). Treatments 3, 5, 10, 11 and 13 had similar behaviors in the three studied situations (leachate, volatilized and normal), while treatments 7 , 8 and 9 (situation 1) and 5 and 13 (situation 2) were considered highly resistant (HR).

We noted that the efficiency of pure andiroba oil was affected by leaching, with a mass loss of $49.07 \%$ (treatment 2, situation 1), being classified as nonresistant. Higher mass losses observed for this situation are probably due to dragging of compounds present in the oil, leaving them less protected against the fungus action. Vital et al. (2001) explained that wood treated with solutions affected by leaching will probably lose efficiency if used in contact with the soil or subjected to bad weather.

Revista Árvore 2020;44:e4430 
The Pinus wood changed its color to brownishblack after being attacked by the fungus. This situation occurred since brown rot fungi digest and assimilate cellulose and hemicelluloses, leaving the lignin which acquires a darker color, as it is a component which is little or not assimilable by these fungi (Zabel and Morreal, 1992; Goodell et al., 2003; Schmidt, 2006).

When evaluating the efficiency of natural products in the treatment of Pinus caribaea wood on the action of Postia placenta fungus, Teixeira et al. (2015) found that neem oil (Azadirachta indica) provided a protective effect, but significantly inferior to the other evaluated products, which were the natural terpene residues of candeia (Eremanthus erythropappus) and bisabolol resin. Although neem oil provided the greatest mass loss, it was considered efficient since the treated samples lost an average of $16.94 \%$ of their mass, which corresponds to $59.72 \%$ less when compared to non-treated wood $(42.05 \%)$ (Teixeira et al., 2015). Therefore, there are natural products which are effective against xylophagous fungi and can be indicated for wood protection.

There are studies which prove that antimicrobial activities of vegetable oils are provided by the chemical composition and the functional groups present in them; however, each of these has its peculiarity and specific action on microorganisms, whether they are bacteria, fungi or protozoa (Reschke et al., 2007; Valeriano et al., 2012).

\subsection{Soft rot assay}

There were trends in improving the wood resistance with the enrichment of iodine $\left(\mathrm{I}_{2}\right)$ in situation 3 - normal (Table 5), which was confirmed by the decrease in mass loss. Pure oils in this situation (3) obtained the highest mass losses with values of $7.55 ; 4.49$; and $6.15 \%$ for andiroba, copaiba and jatropha oils (treatments 2,6 and 10), respectively.

The lowest mass loss average $(0.57 \%)$ in the normal situation was found for treatment 5 , which corresponds to andiroba oil enriched with $5 \% \mathrm{I}_{2}$. This treatment did not statistically differ from jatropha oil enriched with $3 \%$ and $5 \% \mathrm{I}_{2}$, with the latter two not being influenced by leaching or volatilization.

The mass losses in treatments 4, 7, 8, 12 and 13 in situations 1, 2 and 3 showed similar behaviors. We observed that the treatments with pure andiroba oil enriched with $1 \% \mathrm{I}_{2}$ (treatments 2 and 3), respectively, did not statistically differ from the control in the leached situation (1).

Both pure and enriched with $\mathrm{I}_{2}$ andiroba oil (treatments 2, 3, 4 and 5) did not differ (volatilized situation). There was an improvement in the wood resistance treated with copaiba oil when enriched with I2 (situations 2 and 3), because there was a decrease in mass loss as the concentration of this element in the oil increased.

Mass losses were found in a study when analyzing the behavior of Pinus wood submitted to the soft rot test, varying between 2 and $5 \%$, with it being possible to observe that the degradation of this wood was inferior to teak sapwood (Tectona grandis), thereby evidencing the resistance of conifers in relation to hardwoods (Brocco et al., 2017). The results of mass loss found by Brocco et al. (2017) was lower than that in the present study $(14.25 \%)$ in the normal situation (situation 3$)$. The method proposed by IPT/DIMAD D-5 (1980) used in the experiment considers that only mass losses equal to or greater than $3 \%$ are attributed to the attack of soft rot fungi.

We found mass loss values of $24.32 \%$ when carrying out the soft rot test with Pinus elliotti wood. In an experiment in which other species were used, it was noted that the most resistant woods were Myracrodruon urundeuva, Schinopsis brasiliensis and Aspidosperma pyrifolium with mass losses of approximately eight times smaller when compared to Pinus wood, with these values corresponding to $2.48 ; 2.98$; and $2.71 \%$, respectively. In addition, the most deteriorated were Tabebuia aurea and Amburana cearenses (24.26 and $22.78 \%$ ), with mass losses close to that found for the Pinus sp. control (Paes et al., 2005b).

The wood used in this experiment showed a darker color after being subjected to the decay test, and this was noticed after comparing it with a sample not attacked by soft rot fungi. Goodell et al. (2003) and Schmidt (2006) reinforce that the wood attacked by these fungi has a darker surface layer and has small cracks parallel and perpendicular to the grain. There are other characteristics which were visualized by Savory in 1954, cited by Zabel and Morreal (1992), that the surface is macroscopically softened and microscopically the attack is greater inside the secondary cell wall when the wood is attacked by these fungi.

Revista Árvore 2020;44:e4430 


\section{CONCLUSIONS}

Pure andiroba and jatropha oils were the least efficient for controlling the Trametes versicolor fungus in the accelerated decay biological assay. In addition, the leachate situation promoted less mass loss. The wood treated with pure copaiba oil (normal situation) was classified as non-resistant in the control of the Postia placenta fungus.

In the soft rot test, we observed that there were tendencies to improve the wood resistance (normal situation) with an increase in the iodine concentration $\left(\mathrm{I}_{2}\right)$. Therefore, the product can be used to treat wood against soft rot fungi.

The tested natural oils (pure or enriched with I2) provided improvements in the decay resistance of Pinus elliottii wood, even when subjected to aging situations (leaching and volatilization). This indicates that they have persistence in the wood and could be used for wood treatment in places of exposure with less risk to humans.

Although the laboratory test indicated the properties and efficiency of natural products, tests are required in field conditions of decay or service in order to have exact conclusions and prove the true efficacy of the oils and solutions tested, which demands more time and higher costs.

\section{REFERENCES}

American Society for Testing and Materials - ASTM. ASTM D-1413: standard test method for wood preservatives by laboratory soil-block cultures. West Conshohocken: ASTM; 2008. 7 p.

American Society for Testing and Materials - ASTM. ASTM D-2017: standard method of accelerated laboratory test of natural decay resistance of woods. West Conshohocken: ASTM; 2008. 5 p.

Appel JSL, Terescova V, Rodrigues VCB, Vargas VMF. Aspectos toxicológicos do preservativo de madeira CCA (arseniato de cobre cromatado): revisão. Revista Brasileira de Toxicologia. 2006;19(1):33-47.

Arruda FP, Beltrão NEM, Andrade AP, Pereira WE, Severino LS. Cultivo de pinhão manso (Jatropha curca L.) como alternativa para o semi-árido nordestino. Revista Brasileira de Oleaginosas e Fibrosas. 2004;8(1):789-99.
Balfas J. Impregnation of teak extract and resins in rubberwood and fast-grown teak wood. Journal of Tropical Forest Science. 2019;31(2):189-99. doi: 10.26525/jtfs2019.31.2.189199

Bossardi K, Barreiros RM. Produtos naturais como preservantes para madeiras de rápido crescimento: uma revisão. Revista Ciência da Madeira. 2011;2(2):109-18. doi: 10.15210/cmad.v2i2.4030

Brocco VF, Paes JB, Costa LG, Brazolin S, Arantes MDC. Potential of teak heartwood extracts as a natural wood preservative. Journal of Cleaner Production. 2017;142(4):2093-99. doi: 10.1016/j. jclepro.2016.11.074

Carvalho DE, Santini EJ, Gouveia FN, Rocha MP. Resistência natural de quatro espécies florestais submetidas a ensaio com fungos apodrecedores. Floresta e Ambiente. 2015;22(2):271-76. doi: $10.1590 / 2179-8087.105914$

Costa AF, Gonçalez JC, Vale AT. Eficiência de um composto de iodo orgânico contra fungos apodrecedores de madeiras e térmitas. Ciência Florestal. 2003;13(1):145-52. doi: $10.5902 / 198050981733$

Cowan MM. Plant products as antimicrobial agents. Clinical Microbiology Reviews. 1999;12(4):564-82. doi: 10.1128/CMR.12.4.564

Craveiro AA, Machado MIL. De aromas, insetos e plantas. Ciência Hoje. 1986;4(23):54-63.

Deus RJA, Alves CN, Arruda MSP. Avaliação do efeito antifúngico do óleo resina e do óleo essencial de copaíba (Copaifera multijuga Hayne). Revista Brasileira de Plantas Medicinais. 2011;13(1):1-7. doi:10.1590/S1516-05722011000100001

Freitas AR. Métodos de avaliação de preservativos em laboratório. Preservação de Madeiras. 1970;1(3):151-73.

Freire DCB, Brito-Filha CRC, Carvalho-Zilse GA. Efeito dos óleos vegetais de andiroba (Carapa $\mathrm{sp.)}$ e Copaíba (Copaifera sp.) sobre forídeo, pragas de colméias, (Diptera: Phoridae) na Amazônia Central. Acta Amazônica. 2006;36(3):3-8. doi:10.1590/ S0044-59672006000300012

Gonçalves VA. Levantamento de mercado de 
produtos florestais não-madeireiros: Floresta Nacional do Tapajós. Santarém: Promanejo-Ibama; 2001.

Goodell B, Nicholas DD, Schultz TP, editors. Wood deterioration and prevention: advances in our changing world. Washington, DC: American Chemical Society; 2003. (ACS Symposium Series, 845). ISBN-13 9780841237971

Instituto de Pesquisas Tecnológicas do Estado de São Paulo/Divisão de Madeira. IPT/DIMAD - D5: ensaio acelerado de laboratório para determinação de eficiência de preservativos contra fungos de podridão mole. São Paulo: IPT/ DIMAD; 1980. 2 p. (Publicação IPT, 1157).

Leite FHF, Pastore Júnior F. Projeto ITTO PD 31/99 Rev. 3 (I): produção não-madeireira e desenvolvimento sustentável na Amazônia. Análise e crítica tecnológica: copaíba. Brasília: ITTO/ UnB; 2003.

Medeiros FCM, Gouveia FN, Bizzo HR, Vieira RF, Del Menezzi CHS. Fungicidal activity of essential oils from Brazilian Cerrado species against wood decay fungi. International Biodeterioration \& Biodegradation. 2016;114:87-93. doi: 10.1016/j. ibiod.2016.06.003

Moriya T, Módena JLP. Assepsia e antissepsia: técnicas de esterilização. Medicina (Ribeirão Preto). 2008;41(3):265-73.

Oliveira HN, Santana AG, Antigo MR. Atividade inseticida dos óleos de pinhão-manso (Jatropha curcas L.) e nem (Azadirachta indica A. Juss.) em ovos de Diatraea saccharalis (Fabr., 1794) (Lepidoptera: Crambidae). Arquivos do Instituto Biológico. 2013;80(2):229-32. doi: 10.1590/S180816572013000200013

Paes JB, Fonsêca CMB, Lima CR, Souza AD Eficiência do óleo de candeia na melhoria da resistência da madeira de sumaúma a cupins. Cerne. 2010;16(2):217-25. doi: 10.1590/S010477602010000200014

Paes JB, Moreschi JC, Lelles JG. Avaliação do tratamento preservativo de moirões de Eucalyptus viminalis Lab. e de bracatinga (Mimosa scabrella Benth.) pelo método de substituição da seiva. Ciência Florestal. 2005a;15(1):75-86. doi:

\section{$10.5902 / 198050981825$}

Paes JB, Souza AD, Lima CR, Souza PF. Eficiência dos óleos de nim (Azadirachta indica) e mamona (Ricinus communis) na resistência da madeira de sumaúma (Ceiba pentandra) a fungos xilófagos em simuladores de campo. Ciência Florestal. 2012;22(3):617-24. doi: 10.5902/198050986627

Paes JB, Morais VM, Lima CR. Resistência natural de nove madeiras do semiárido brasileiro a fungos causadores da podridão-mole. Revista Árvore. 2005b;29(3):365-71. doi: dx.doi.org/10.1590/S010067622005000300003

Reschke A, Marques LM, Mayworm MAS. Atividade antibacteriana de Ficus benjamina L.(Moraceae). Revista Brasileira Plantas Medicinais. 2007;9(2):67-70.

Revilla J. Plantas da Amazônia: oportunidades econômicas e sustentáveis. 3. ed. Manaus: SEBRAE/ INPA; 2001. ISBN 858732411X.

Schmidt O. Wood and tree fungi: biology, damage, protection, and use. Berlin: Springer; 2006. ISBN-10 3540321381

Sousa SF, Paes JB, Arantes MDC, Lopes Junior DV, Nicácio MA. Efficiency of vegetable oils in wood resistance to Cryptotermes brevis termites. Floresta e Ambiente. 2019;26(2): e20170780. doi: $10.1590 / 2179-8087.078017$

Steel RGD, Torrie JH. Principles and procedures of statistics: a biometrical approach. $2^{\text {nd }}$. ed. New York: McGraw-Hill; 1980. ISBN-10 0070610282.

Takahashi M, Tsunoda K, Imamura Y, Adachi A, Nishimoto K. Studies on the production of preservative-treated plywood (1): preservative effectiveness of glue-line treated plywood with low toxicity chemicals. Mokuzai Hozon. 1985;11(2):11-24.

Teixeira JG, Latorraca JVF, Trevisan H, Paes JB. Eficiência do óleo de neem e dos resíduos de candeia sobre a inibição do desenvolvimento de fungos xilófagos. Scientia Forestalis. 2015;43(106):417-26.

Valeriano C, Piccoli RH, Cardoso MG, Alves E. Atividade antimicrobiana de óleos essenciais em bactérias patogênicas de origem alimentar. Revista 
Brasileira de Plantas Medicinais. 2012;14(1):57-67. doi: 10.1590/S1516-05722012000100009

Vital BR, Shimada AN, Valente OF, Della Lucia RM, Pimenta AS. Avaliação dos taninos da casca de Eucalyptus grandis W. Hill ex Maiden como preservativo de madeira. Revista Árvore. 2001;25(2):245-56.

Zabel RA, Morreal JJ. Wood microbiology: decay and its prevention. New York: Academic Press; 1992. ISBN 9780127752105. 